\title{
APPLICATION OF A REALISTIC APPROACH TO IMPROVE THE ABILITY OF MATHEMATICAL PROBLEM SOLVING AND SELF REGULATED LEARNING OF JUNIOR HIGH SCHOOL STUDENTS
}

\author{
Rina Krisnawati ${ }^{1}$, Euis Eti Rohaeti ${ }^{2}$, Rippy Maya ${ }^{3}$ \\ ${ }^{1}$ SMPN.4 Subang \\ 2,3IKIP Siliwangi \\ rina.krisnawati.suwardi@gmail.com \\ Received: June, 2018; Accepted: June, 2018
}

\begin{abstract}
This study is a quasi-experimental research, which aims to examine the achievement and improvement of problem solving skills of mathematics and the independence of junior high school students learning through realistic approach. The population in this study is all students of class VIII SMPN 4 Subang. Samples were taken by random class, obtained two classes of class VIII $\mathrm{H}$ as experimental class and VIII.F as control class. The instrument in this study is a set of mathematical problem solving test and a set of learning independence scales. The study found that the achievement and improvement of students' mathematical problem-solving skills, and the independence of student learning whose learning using realistic learning is better than that of learning using ordinary learning in terms of the initial ability level of students. There is an interaction of mathematical problem-solving abilities between students whose learning uses a realistic approach with a student's initial ability level. Meanwhile, there is no interaction between realistic learning with the level of initial ability of students in generating student self-reliance. Besides, there is no association between mathematical problem solving ability and student learning independence, both in class that use realistic and classroom learning using ordinary learning. The picture of student's performance during realistic learning is more active, it shows the involvement of students both individually and in collaboration with the group, so that it can improve the problem solving ability of mathematics as well as student's learning independence. The description of the students' difficulties in solving the problem of mathematical problem solving ability lies in the indicator about number 5 which is about making the mathematical model because the lowest percentage indicator.
\end{abstract}

Keywords: Mathematical Problem Solving, Self Regulated Learning, Realistic Approach

\begin{abstract}
Abstrak
Penelitian ini merupakan penelitian kuasi eksperimen, yang bertujuan untuk menelaah pencapaian dan peningkatan kemampuan pemecahan masalah matematik dan kemandirian belajar siswa SMP melalui pembelajaran pendekatan realistik. Populasi dalam penelitian ini adalah seluruh siswa kelas VIII SMPN 4 Subang. Sampel diambil secara acak kelas, diperoleh dua kelas yaitu kelas VIII H sebagai kelas eksperimen dan VIII.F sebagai kelas kontrol. Instrumen dalam penelitian ini adalah satu set tes uraian pemecahan masalah matematik dan satu set skala kemandirian belajar. Penelitian menemukan bahwa pencapaian dan peningkatan kemampuan pemecahan masalah matematika siswa, dan kemandirian belajar siswa yang pembelajarannya menggunakan pembelajaran realistik lebih baik daripada yang pembelajarannya menggunakan pembelajaran biasa ditinjau dari tingkat kemampuan awal siswanya. Terdapat interaksi kemampuan pemecahan masalah matematik antara siswa yang
\end{abstract}


86 Krisnawati, R., Rohaeti, E. E., Maya, R. Application of a Realistic Approach to Improve the Ability of Mathematical Problem Solving and Self Regulated Learning of Junior High School Students

pembelajarannya menggunakan pendekatan realistik dengan tingkat kemampuan awal siswa. Sementara itu, tidak terdapat interaksi antara pembelajaran realistik dengan tingkat kemampuan awal siswa dalam menghasilkan kemandirian belajar siswa. Selain itu tidak ditemukan asosiasi antara kemampuan pemecahan masalah matematik dan kemandirian belajar siswa, baik di kelas yang menggunakan pembelajaran realistik maupun di kelas yang menggunakan pembelajaran biasa. Gambaran kinerja siswa selama pembelajaran realistik lebih aktif, kreatif memperlihatkan keterlibatan siswa baik secara individu maupun dalam bekerjasama dengan kelompoknya, sehingga dapat meningkatkan kemampuan pemecahan masalah matematik serta kemandirian belajar siswa tersebut. Gambaran kesulitan siswa dalam menyelesaikan soal-soal kemampuan pemecahan masalah matematik terletak pada indikator soal nomor 5 yaitu tentang membuat model matematika karena indikator persentasenya paling rendah.

Kata Kunci: Pemecahan Masalah Matematik, Kemandirian Belajar Matrematik, Pendekatan Realistik

How to Cite: Krisnawati, R., Rohaeti, E. E., Maya, R. (2018). Application of a Realistic Approach to Improve the Ability of Mathematical Problem Solving and Self Regulated Learning of Junior High School Students. JIML, 1 (2), 85-91.

\section{INTRODUCTION}

Problem solving can improve the ability to think critically, logically, and systematically this is in accordance with the mindset studied by the method of learning that uses a realistic approach. Based on Permendiknas Number 22 of 2006 on Subject Content Standards, one of the objectives of junior mathematics subjects is for students to be able to solve math problems covering problems, mathematical model problems, model and model of settlement obtained (MoNE, 2006). Problem solving is still seen as the most difficult part in mathematics both by students in learning it and for teachers in membelajarkannya. Different things arise, among others, because looking for answers to the only goal to be achieved, because it is the only answer in choosing a particular technique appropriate (Susilawati, 2014).

Hendriana and Sumarmo (2017), argued that solving mathematical problems as a process involves several activities: identifying the adequacy of elements for problem solving, selecting and implementing strategies to solve problems, carrying out calculations, and interpreting solutions to the original problem and checking the correctness of the solution. Independence is the ability to perform activities or daily tasks alone or with little guidance in accordance with the stages of development and capacity, independence of learning is a condition or condition of learning activities with their own ability without depending on others, always consistent and eager to learn wherever and whenever. Independence is important because every independence aims in order to direct itself towards positive behavior that can support success in the learning process. With the independence of learning, students have clear goals, assess themselves, consider the progress of learning, such as high views and beliefs about the ability of himself, the value of learning, factors that influence in learning, and anticipation during the learning process.

According to Harvest et al (Sundayana, 2015) asserted that the independence of learning is a process in which the students control their own learning process and the purpose of the 
learning. The main feature in self-learning is not the absence of teachers or fellow students or the absence of face-to-face meetings in the classroom but the development of students' ability to do the learning process that does not depend on the factors of teachers, friends, classes and others.

Afgani, (2011), states that to improve the success in solving problems requires intelligence, good reason, perform good calculations, able to read well and have good ownership. One of the mathematics learning that allows students to develop the ability of mathematical thinking is Realistic Mathematics Education (RME). RME is a learning based on constructivism philosophy aimed at improving mathematics education in Indonesia. According to Soedjadi (Riyadi, 2013), the Realistic approach provides an opportunity for students to find their own mathematical concepts in solving problems.

Based on the results of research conducted by Palinussa (2009),) and stated that Realistic Mathematics Education (RME) as one of the innovative learning that helps teachers to teach math to students and set them to improve students' math skills. RME is in line with KTSP (Depdiknas, 2006) which advocates contextual issues in initiating mathematics learning activities and prioritizing character development.

Learning using a realistic approach provides the widest opportunity for students to understand a problem, then perform various activities to solve the problem through doing mathematick such as modeling problems, discussing, doing reflection, and finally finding problem solving by finding various concepts, principles, as well as algorithms in mathematics.

\section{METHOD}

In this research used quasi experimental research, with research design in the form of "Pretes Postes, in this research involving two classes, first class that is experiment class which is given learning of Realistic approach while second class is control class which will be given learning of math by using ordinary learning .

Before and after the treatment the two classes received parallel tests of pretest and posttest tests so that the experimental design used was the non-equivalent control design as follows:

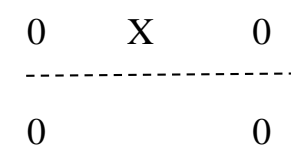

Information:

$0 \quad$ : Pretest $=$ posttest mathematical problem solving ability.

$\mathrm{X} \quad$ : Learning with a realistic approach

: The sampling is not subject random

\section{RESULTS AND DISCUSSION}

\section{Results}

The TKAS test was conducted to determine the level of students' early math ability. Students from the experimental class and control class are grouped based on the students' high level of 
88 Krisnawati, R., Rohaeti, E. E., Maya, R. Application of a Realistic Approach to Improve the Ability of Mathematical Problem Solving and Self Regulated Learning of Junior High School Students

mathematics ability (TKAS) that is high, medium and low. The grouping of TKAS is taken from the result of the test of the mathematical ability ability made by the researcher. Student grouping criteria were based on the mean score $\left(\mathrm{X}^{\overline{ }}\right)$ and standard deviation $(\mathrm{S})$, the criteria for grouping the students scores refer to Rahayu and Maman (2012: 121)

The result of TKAS between the two classes was not significantly different, seen from the high qualification data of the experimental class average value $(\mathrm{X})^{-}=71,8$ and the control class average value $(\mathrm{X})^{-}=71.3$ medium qualification experimental class $(\mathrm{X})^{-}=56.6$ and the control class average value $(\mathrm{X})^{-}=56.6$, while low qualifications mean experiment class grade $(\mathrm{X})^{-}=40.9$ and average value $(\mathrm{X})^{-}=56.8$ and the overall mean value (total) of the control class $(\mathrm{X})^{-}=56.7$, while the overall mean value (total) of the experimental class $(\mathrm{X})^{-}=56.7$, that the experimental class and the control class do not have different mathematical initial abilities.

The result of research for mathematical problem solving ability and student's mathematical learning independence are as follows:

Table 2

Anova Test Two Path Mathematical Problem Solving Abilities Based on Realistic Approach

Tests of Between-Subjects Effects

\begin{tabular}{llllll}
\hline \multirow{2}{*}{ Source } & \multicolumn{5}{l}{ Type III Sum of } \\
& Squares & Df & Mean Square & F & Sig. \\
\hline Corrected Model & $839,834^{\mathrm{a}}$ & 5 & 167,967 & 32,723 &, 000 \\
\hline & 22574,917 & 1 & 22574,917 & 4398,005 &, 000 \\
\hline kelas & 441,856 & 1 & 441,856 & 86,082 &, 000 \\
\hline TKAS & 196,204 & 2 & 98,102 & 19,112 &, 000 \\
\hline kelas * TKAS & 36,485 & 2 & 18,242 & 3,554 &, 034 \\
\hline Error & 338,777 & 66 & 5,133 & & \\
\hline Total & 28948,000 & 72 & & & \\
\hline Corrected Total & 1178,611 & 71 & & & \\
\hline
\end{tabular}

The value of significance $=0,000<0.05$, it can be concluded that there are significant differences in achievement between students' mathematical problem solving abilities, the learning using Realistic approach with the learning using ordinary learning, meaning the ability to solve mathematical problems between the experimental class and control class there significant difference in achievement.

Table 3

Anova Test Two Paths Scale Attitudes Independence of Mathematical Learning Based on Realistic Approach and TKAS

Tests of Between-Subjects Effects

Dependent Variable: NILAI

\begin{tabular}{lllll}
\hline Source & $\begin{array}{l}\text { Type III Sum of df } \\
\text { Squares }\end{array}$ & Mean Square & S & Sig. \\
\hline
\end{tabular}




\begin{tabular}{llllll}
\hline Corrected Model & $5293,439^{a}$ & 5 & 1058,688 & 34,730 &, 000 \\
\hline & 275968,303 & 1 & 275968,303 & 9053,178 &, 000 \\
\hline KELOMPOK & 172,798 & 1 & 172,798 & 5,669 &, 020 \\
\hline TKAS & 4846,321 & 2 & 2423,161 & 79,492 &, 000 \\
\hline KELOMPOK ${ }^{*}$ TKAS & 9,432 & 2 & 4,716 &, 155 &, 857 \\
\hline Error & 2011,880 & 66 & 30,483 & & \\
\hline Total & 493239,000 & 72 & & & \\
\hline Corrected Total & 7305,319 & 71 & & & \\
\hline a. R Squared $=, 725$ (Adjusted R Squared $=, 704)$ & & &
\end{tabular}

The value of significance $=0,000<0.05$, it can be concluded that there is a significant difference in the scale of the students' independent attitude of learning mathematics, between the learning using Realistic approach with the learning using ordinary learning.

To find out whether there is an association between Problem Solving abilities and learning independence of Mathematics used Chi-Square test (X2).

\section{Table 4}

\section{Chi-Square Test $\left(\mathrm{X}^{2}\right)$}

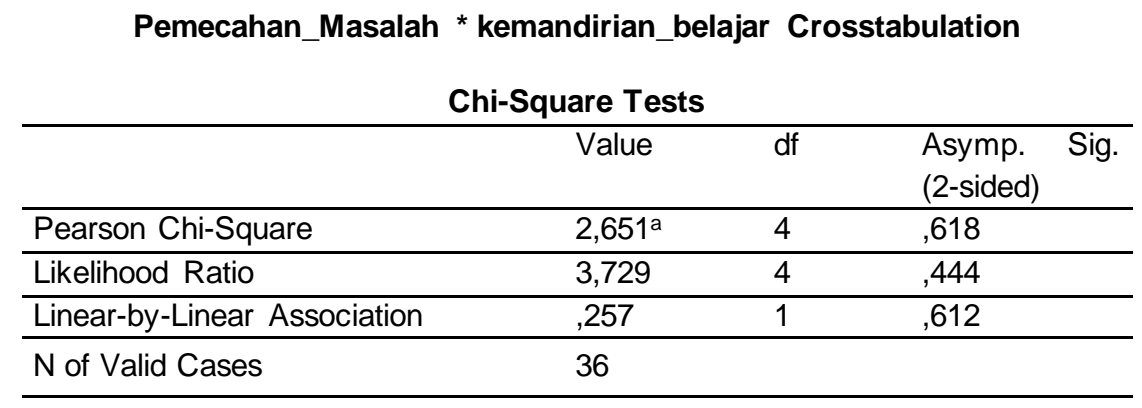

Pearson Chi-Square in the table is 0.618 the value meets the criteria of more than 0.05 , then Ho accepted which means there is no significant association between Problem Solving abilities and Mathematical learning independence.

\section{Discussion}

The results of the experimental class data analysis and control class using KolmogorovSmirnov test and Levene test where the two classes have significance value greater than the significant used Ho then rejected which means the sample comes from a population of normal and homogeneous distribution, then followed by the $\mathrm{T}$ test Independent Sample $\mathrm{T}$ Test with value of sig $(1$-tailed $)=0.000$ smaller than significant used, then $\mathrm{H} 0$ is rejected this shows that after learning achievement of problem solving ability of student mathematics in experiment class using learning by using Realistic approach better than the control class whose learning uses ordinary learning.

Furthermore, n-Gain data analysis of normalized experimental class and control class using Kolmogorov-Smirnov test showed significance value for experimental class is greater than significant used then the population is normally distributed, while for the control class showed less significant significance value that used then the population is not normally distributed, 
90 Krisnawati, R., Rohaeti, E. E., Maya, R. Application of a Realistic Approach to Improve the Ability of Mathematical Problem Solving and Self Regulated Learning of Junior High School Students

because one of the population is not normally distributed, it is directly tested two averages using Mann-Whitney test with less significant significance value used, Ho is rejected which means the improvement of students' mathematical problem solving skills in the experimental class using Realistic approaches are better than control classes whose learning uses ordinary learning.

Based on the results of statistical data processing using Kolmogorov-Smirnov test and Levene test where the two classes have significant significance value greater than the significance used then Ho is rejected which means the sample comes from a population of normal and homogeneous distribution, then continued with $\mathrm{T}$ test Independent Sample $\mathrm{T}$ Test, with significance value less than significant that is used, then Ho is rejected which means there is a difference of mathematical learning independence between experimental class and control class. Based on the achievement of learning independence indicates that, students' mathematical independence can be increased higher by using a realistic approach that learning activities require liveliness, cooperative skills and groups.

The result of association test on problem solving ability and independence of mathematic learning with contingency coefficient value is 0,618 value that fulfill criterion more than 0,05 , hence Ho accepted meaning there is no significant association between problem solving ability and mathematics learning independence. This shows that the independence of mathematical learning can not affect the ability of problem solving mathematics.

Based on the results of the research being analyzed using two-track Anova for students' mathematical problem solving abilities with sig $=0,034<0,05$ means that there is interaction of mathematical problem solving ability among students whose learning using realistic approach in high, medium and low TKAS with students whose learning is using ordinary learning on high, medium and high TKAS low.

Furthermore, for the independence of students' mathematical learning, based on the results of research analyzed by using two-sided Anova sig $=0.857>0.05$ it can be concluded that there is no significant interaction of mathematical learning independence between students whose learning using realistic approach on high TKAS, medium and low with students whose learning uses regular learning on high, medium and low TKAS.

\section{CONCLUSION}

Based on the results of data processing and discussion that has been done before, obtained some conclusions as follows:

1. Achievement and improvement of mathematical problem solving ability of junior high school students whose learning using realistic approach is better than those using ordinary learning reviewed overall and based on TKAS (high, medium and low group). The achievement and improvement of the problem solving skills of the two classes are moderate.

2. There is a significant difference in the scale of students 'learning attitudes of students' learning independence, with learning using the Realistic approach and the learning using 
ordinary learning reviewed overall and based on TKAS (high, medium and low group). Where the autonomy of learning mathematics students of both classes are moderate.

3. There is no significant association between Problem Solving abilities and mathematics learning independence of junior high school students.

4. There is interaction of ability Problem solving of mathematics between student whose learning using realistic approach at high TKAS, medium and low with students whose learning using ordinary learning on high TKAS, medium and low.

5. There is no interaction of autonomy of learning mathematics between students whose learning using realistic approach at high TKAS, medium and low with students whose learning using ordinary learning on high TKAS, medium and low.

\section{REFERENCES}

Afgani, J.D (2011), Analisis Kurikulum Matematika. Jakarta Universitas Terbuka.

Depdiknas. (2006) Standar Isi dan Standar Kompetensi lulusan Beserta Kerangka Dasar dan Struktur kurikulum untuk Satuan pendidikan sekolah Menengah Pertama (SMP) Madrasah Tsanawiyah (MTs) beserta Peraturan Pelaksanaannya. Jakarta : Departemen Pendidikan Nasional Republik Indonesia.

Hendriana. H dan Sumarmo, U (2017). Penilaian Pembelajaran Matematika (Edisi Revisi). PT Refika Aditama. Bandung.

Palinusa, AL (2009). Pembelajaran Matematika Realistik untuk materi belah ketupat dan layang-layang dikelas VII SMP Negeri 19 Ambon”. Mathedu Jurnal Pendidikan Matematika PPs Unesa. Vol.4 no.1 Januari 2013, pp 75-94.

Permendiknas, (2006), Standar Isi dan Standar Kompetensi Lulusan Beserta Kerangka Dasar dan Struktur Kuriulum untuk Satuan Pendidikan Sekolah Menengah Pertama (SMP/MTs) Beserta Peraturan Pelaksanaannya, Jakarta: Departemen Pendidikan Nasional Republik Indonesia.

Rahayu, K dan Maman, A (2012:121) Dasar-dasar Statistik Pendidikan, Penerbit PUSTAKA SETIA Bandung.

Soedjadi, R (2000) Kiat Pendidikan Matematika di Indonesia. Jakarta: DIKTI.

Sundayana, R (2015) Journal "Kaitan antara Gaya Belajar, Kemandirian Belajar, dan Kemampuan Pemecahan Masalah Siswa SMP dalam Pembelajaran, STKIP Garut. [Tidak diterbitkan]

Susilawati, W (2014) Belajar dan Pembelajaran Matematika.CV. Insan Mandiri. Bandung. Wardani, S (2002) Pembelajaran Pemecahan Masalah Matematika melalui Model Kooperatif Tipe Jigsaw. Tesis pada PPs UPI. Bandung. 